\title{
Mitogen-Activated Protein Kinase 3
}

National Cancer Institute

\section{Source}

National Cancer Institute. Mitogen-Activated Protein Kinase 3. NCI Thesaurus. Code C17408.

Mitogen-activated protein kinase 3 (379 aa, $\sim 43 \mathrm{kDa}$ ) is encoded by the human MAPK3 gene. This protein plays a role in transcriptional regulation, serine/threonine phosphorylation and both cytokine-dependent and stress-activated signaling. 